\title{
Study on Gypsum Plasters with Modified Waste Mycelium as Retarder
}

\author{
Liang Jichen $^{1, \mathrm{a}}$,Li zihui ${ }^{1}$,Yan xiaoya ${ }^{1}$, Ren Xiaoqiong ${ }^{1,2}$,Zhao \\ Fengqing ${ }^{1, \mathrm{~b}}$ \\ ${ }^{1}$ Hebei University of Science \& Technology, Shijiazhuang 050018, PR \\ China \\ ${ }^{2}$ Hebei Engineering Research Center of Pharmaceutical and Chemical \\ Engineering \\ Shijiazhuang 050018, PR China \\ ${ }^{a}$ e-mail: \\ 695233024@qq.com,bemail:zhaofq3366@126.com(corresponding \\ author)
}

\begin{abstract}
As new type of indoor decoration materials, gypsum plasters have good development prospect in fire resistance, heat preservation and insulation, environmental protection, etc. The purpose of this paper is to prepare gypsum plaster using desulphurization gypsum, waste mycelium retarder (WPM) and some additives. The formulation of surface gypsum plaster was obtained: desulfurization gypsum $93 \%$, cement $2 \%$, granulated blast-furnace slag $4 \%$, water retention agent $1 \%$, water reducing agent $0.05 \%$, WPM retarder $0.06 \%$. The base plaster was obtained by mixing surface gypsum plaster with medium sand in mass ratio of 1:1. 5. The thermal insulation gypsum plaster was prepared with surface gypsum plaster and perlite by mass ratio of 5:1.8. The products conform to (JCT517-2004) standards.
\end{abstract}

Keywords: Gypsum plaster; WPM retarder; Desulfurization gypsum

\section{Introduction}

Gypsum plasters as lightweight, heat preservation and insulation and fire resistance materials, have the reputation of green building materials and show 
good prospects for development and application. Flue gas desulfurization gypsum (FGD) is a byproduct of the wet desulfurization equipment of power plant. It has many advantages, for instance, light in quality, fire resistance and harmless to human [1]. But the disadvantage for FGD is very short setting time which usually lasts several minutes. It cannot meet the requirements for construction operating time, so, the retarder is often added in the gypsum to adjust the setting time [2]. Common gypsum retarders include organic citric acid, sodium polyphosphate and protein based materials. Compared with sodium citrate and sodium polyphosphate, protein based materials can effectively prolong the setting time of hemi-hydrate gypsum with less influence on mechanical strength values of gypsum block [3-4].

Waste penicillin mycelium (WPM) is a harmful solid waste from the production process of penicillin in pharmaceutical factory. According to the survey, the major of antibiotics producers produced hundreds of thousands tons of waste mycelium annually. If not effectively handled, it will bring thorny issues to the manufacturers and will cause serious pollution to the environment [5]. It was found that waste mycelium contains a large amount of proteins which has recycling value. Protein can extend the setting time of gypsum. In this paper, a new kind of gypsum retarder was prepared from WPM, and added it in gypsum plaster, which provides a new way for the resource utilization of WPM.

\section{Experimental}

Materials. Desulfurization gypsum used in this paper was provided by Xibaipo power plant, shijiazhuang, hebei. The WPM is from North China Pharmaceutical Co., Ltd. China.

Methods. The standard consistency water requirement, setting time and mechanical strength of the building gypsum were tested according to GB/T17669.3-1999 and GB/T17669.4-1999. The standard diffusion water requirement, setting time, operating time, volume density and intensity of gypsum plastering were tested according to JC/T517-2004. 
WPM retarder preparation. A certain amount of penicillin mycelium waste was added into water to modify under a certain condition, the $\mathrm{pH}$ value 11 , temperature $80{ }^{\circ} \mathrm{C}$ and treatment time $1.5 \mathrm{~h}$, then filtrated, and the filtrate is the WPM retarder solution.

Preparation of gypsum plasters. Firstly, prepare the surface gypsum plaster, then prepare the base plaster by the mass ratio of surface gypsum plaster and medium sand is $1.5 \sim 2.0$. Finally, medium sand in base plaster is replaced with an approximate same volume ratio of expanded perlite, the thermal insulation gypsum plaster was prepared.

\section{Results and discussion}

The preparation of the surface gypsum plaster. The formula of surface gypsum plaster is shown in table 1 , and the results are shown in Table 2.

Table 1 The formula of surface gypsum plaster

\begin{tabular}{cccccc}
\hline Component & FGD & $\begin{array}{c}\text { Superfine } \\
\text { powder }\end{array}$ & cement & HPMC & water reducer \\
\hline Dosage $/ \%$ & 93 & 4 & 2 & 0.5 & 0.5 \\
\hline
\end{tabular}

Table 2 Effect of different dosage of retarder on the surface gypsum plaster 


\begin{tabular}{lccccccccc}
\hline Dosage of retarder/\% & & 0 & 0.01 & 0.03 & 0.06 & 0.08 & 0.10 & 0.15 & Standard requirement \\
\hline \multirow{2}{*}{ Setting time/min } & Initial & 9 & 17 & 31 & 65 & 93 & 154 & 286 & $>60 \mathrm{~min}$ \\
& Final & 14 & 25 & 41 & 75 & 103 & 162 & 395 & $<8 \mathrm{~h}$ \\
water-retention rate $/ \%$ & $/$ & $/$ & $/$ & 92.6 & 90.5 & 87 & 87.7 & $>90 \%$ \\
Workable time/min & $/$ & $/$ & $/$ & \multicolumn{7}{c}{$>0$} & $>30$ \\
Bending strength/MPa & $/$ & $/$ & $/$ & 4.6 & 3.6 & $/$ & $/$ & $>3.0$ \\
Compressive strength/MPa & $/$ & $/$ & $/$ & 6.4 & 4.6 & $/$ & $/$ & $>6.0$ \\
\hline
\end{tabular}

As is shown in the Table 2, the setting time of the surface of gypsum plaster is prolonged with the increase of the WPM retarder. When the WPM retarder content is more than $0.06 \%$, the initial setting time is longer than $60 \mathrm{~min}$, the final setting time is less than $8 \mathrm{~h}$, which meets the standard requirement. However, the results showed that the water-retention rate decreased with the increase of the dosage of retarder. When the dosage of retarder is $0.08 \%$, the water-retention rate is slightly greater than $90 \%$, so the retarder content that makes the water retention satisfying the standard requirement is $0.06 \sim 0.08 \%$. When the retarder dosage is $0.06 \%$ or $0.08 \%$, measure the workable time and mechanical strength values. The results were shown in table 2 . When the dosage of retarder is $0.06 \%$, it can meet gypsum plaster standard (JCT517-2004) requirements. Therefore, the dosage of the WPM retarder should be $0.06 \%$.

From Table 1 and Table 2, the formula of the surface gypsum plaster can be determined. The various performances are shown in Table 3 . The results show the gypsum plasters conform to JCT517-2004 for the surface gypsum plaster.

Table 3 The formula of the surface gypsum plaster and performances 


\begin{tabular}{|c|c|c|}
\hline Item & $\begin{array}{l}\text { Dosage } \\
\text { /Results }\end{array}$ & Standard requirements \\
\hline FGD $/ \%$ & 93 & / \\
\hline Cement /\% & 2 & / \\
\hline Superfine slag powder $/ \%$ & 4 & l \\
\hline WPM retarder $/ \%$ & 0.06 & l \\
\hline Water reducer $/ \%$ & 0.5 & / \\
\hline HPMC $/ \%$ & 0.5 & I \\
\hline Standard consistency water requirement & 0.55 & / \\
\hline Initial setting time /min & 65 & $>60$ \\
\hline Final setting time /min & 75 & $<8 \mathrm{~h}$ \\
\hline Workable time /min & $>30$ & $>30$ \\
\hline Bending strength /MPa & 4.6 & $>3.0$ \\
\hline Compressive strength /MPa & 6.4 & $>6.0$ \\
\hline water-retention rate $\quad / \%$ & 92.6 & $>90$ \\
\hline
\end{tabular}

The preparation of the base gypsum plaster. The base plaster gypsum was prepared according to the mass ratio of surface gypsum plaster: medium sand=1.5:1. The results are shown in Table 4 .

Table 4 Effect of different retarder dosages on the base gypsum plaster

\begin{tabular}{ccc}
\hline & WPM Retader 0.06/\% & Standard requirements \\
\hline Bending strength/MPa & 3.1 & $>2.0$ \\
Compressive strength/MPa & 5.4 & $>4.0$ \\
water-retention rate $\quad / \%$ & 84.2 & $>75$ \\
\hline
\end{tabular}

As is shown in Table 4, the mechanical strength and water-retention rate of the base gypsum plaster conforms to JCT517-2004.

The preparation of the thermal insulation gypsum plaster. Thermal insulation gypsum plaster was prepared by replacing medium sand with expanded perlite in the base gypsum plaster. 


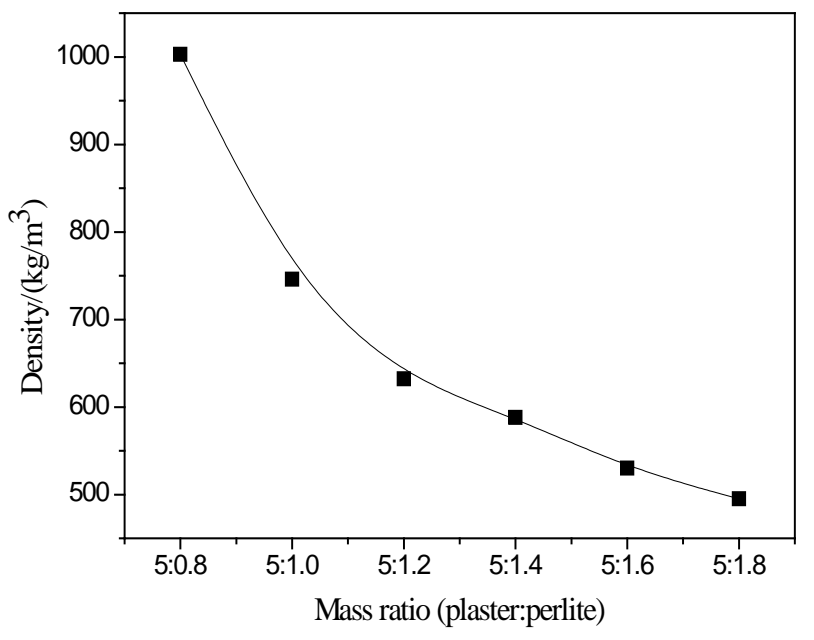

Fig.1 Effects of perlite on density of plaster

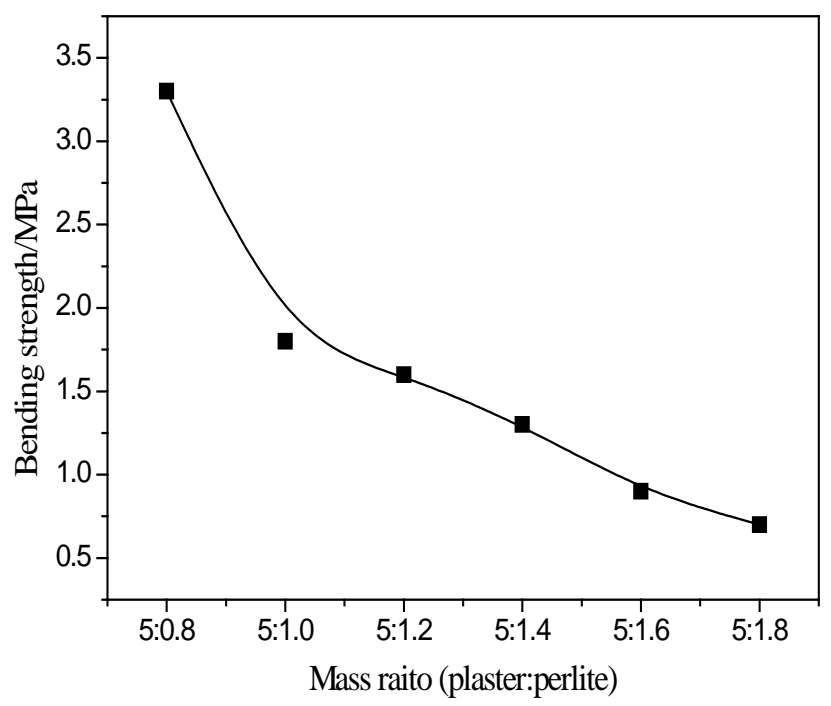

Fig.2 Effects of perlite on the bending strength of plaster

Effect of expanded perlite on density and compressive strength of the thermal insulation gypsum plaster were shown on Fig.1 and Fig.2. 
It can be seen from Fig.1 and Fig.2 that the density and bending strength of plaster decrease with the increase of perlite. When the mass ratio of gypsum plaster: expanded perlite is $5: 1.8$, the volume density is $495 \mathrm{~kg} / \mathrm{m}^{3}$, and the bending strength is larger than $0.6 \mathrm{MPa}$, which meets the standard.

The formula of the thermal insulation gypsum plaster and related parameters were shown in Table 5. The results show that and all the performances meet the requirements of the gypsum plaster Standard requirements.

Table 5 The formula of the thermal insulation gypsum plaster and performances

\begin{tabular}{ccc}
\hline Item & Dosage /Results & Standard requirements \\
\hline Mass ratio of Surface plaster to & $5: 1.8$ & $/$ \\
perlite & & $<500$ \\
Density $\left(\mathrm{kg} / \mathrm{m}^{3}\right)$ & 495 & $/$ \\
Bending strength $/ \mathrm{MPa}$ & 0.6 & $>0.6$ \\
Compressive strength $/ \mathrm{MPa}$ & 0.7 & $>60$ \\
water-retention rate $/ \%$ & 62 & \\
\hline
\end{tabular}

\section{Conclusions}

(1)The formula of the surface gypsum plaster: FGD 93\%, cement $2 \%$, superfine slag $4 \%$, HPMC $0.5 \%$, water reducer $0.5 \%$, WPM retarder $0.06 \%$.(2) The formula of the base gypsum plaster: the mass ratio of surface gypsum plaster and medium sand is 1:1.5.(3) The formula of the thermal insulation gypsum plaster: The mass ratio of surface gypsum plaster and the expanded perlite is 5:1.8.

All the Performance parameters meet the standard requirements of "gypsum plaster" (JC/T517-2004). WPM retarder can be used in gypsum plasters, which showed excellent characteristics and have bright future. 


\section{References}

[1] Li Han. In metope paint the plaster the application of the system [J]. Technology and market, 2012, 3 (19) : 3-4 (In Chinese)

[2] Li qun Zhao, Xin Zhang. Desulphated gypsum plaster developing. Coal ash China, 2006 (3) : 22 - 23 (In Chinese)

[3] Qi biao Feng. Study on building gypsum retarder of gel protein. Xi'an University of Architecture \&Technology, master's thesis ,2006 (In Chinese)

[4] Peng Jia-hui, Peng Zhi-hui, Qu Jin-dong, et al. The negative effects of retarders on structure and strengthof building gypsum [J]. Journal of Harbin Institute of Technology, 2004, 36(9): 1177-1181. (in Chinese)

[5] Xiao qiong Ren, Hong jie Liu, Xue song Liang. Study on Gypsum Retarder from Waste Penicillin Mycelium [J]. Advanced Materials Research Vol. 878 (2014) pp 539-544. 